ORIGINAL PROF-1494

\title{
GROWTH HORMONE THERAPY;
}

\author{
Classic short stature children
}

Dr. Lt. Col Nayyar Ahmad, Dr. Lt. Col. Mohammad Tariq Nadeem, Dr. Maj. Zameer Ahmad Nayyar

ABSTRACT... Objective: To detect growth hormone deficiency in short stature children and to observe the response of growth hormone replacement therapy in isolated GH deficient. Design: An interventional descriptive study. Place and Duration of Study: The study was carried out in the Department of Pediatrics at Military Hospital Rawalpindi in collaboration with Armed Forces Institute of Pathology Rawalpindi over a period of two years from Jan 2007 to Dec 2008. Patients and Methods: Thirty short children between three to fourteen years of age having isolated growth hormone deficiency confirmed by laboratory investigation were included in the study prospectively and retrospectively. Growth hormone replacement therapy with recombinant GH was given to all children at the dose of $0.14 i \mathrm{iu} / \mathrm{kg}$, six days a week subcutaneously. Each patient was assessed and evaluated after every three months. Results: The mean chronologic age was $8.05+/-2.74$ years with a height age of 4.02 years. The male to female ratio was 1.72:1. They were treated with recombinant GH in a dose of $0.14 \mathrm{iu} / \mathrm{kg}$, six days a week, subcutaneously at evening. Response to $\mathrm{GH}$ was excellent and the mean growth speed had gone up from $2.53+/-0.87 \mathrm{~cm}$ per year before the treatment to $8.94+/-3.18 \mathrm{~cm} /$ year in the first twelve months of treatment and $6.8+/-1.6$ $\mathrm{cm} /$ year during the second year of treatment. During the first twenty four months of treatment, height standard deviation score increased by $1.0+/-0.4$ SD $(p<0.0001)$ The height velocity increased, the bone age / chronological age ratio and height SDS for chronological age decreased, while height SDS for bone age increased. There were no adverse reactions. Conclusion: Short stature with classic growth hormone deficiency is not uncommon. Early diagnosis and prompt treatment with growth hormone replacement has a very good outcome and the child attains a reasonable height.

Key words: Classic Short Stature, Growth Hormone, Recombinant GH Therapy.

Article Citation

Ahmad N, Nadeem MT, Nayyar ZA. Growth hormone therapy; classic short stature children. Professional Med J 2013;20(2):182-187.

\section{INTRODUCTION}

Classic short stature occurs in about 1/4000 live births ${ }^{1}$. Growth hormone therapy imroves growth in these children. ${ }^{(2)}$ Since the first use of human growth hormone in 1958 and after the development of recombinant GH in 1985, a large number of short GHdeficient children have been treated, with a remarkably good safety record ${ }^{3,4,5,6}$.

This study was carried out to detect classic growth hormone deficiency in children with short stature and to observe the response to growth hormone therapy in these children.

\section{PATIENTS AND METHODS}

This study was carried out in the Department of Pediatrics at Military Hospital Rawalpindi in collaboration with Department of Chemical Pathology and Endocrinology, Armed Forces Institute of
Pathology Rawalpindi over a period of two years from Jan 2007 to Dec 2008.

Thirty short children referred from various centres in Pakistan including Kashmir and Northern Areas,having isolated growth hormone deficiency, were included in the study. Out of these, six children were those who were diagnosed during the study period.

Twenty four children were already diagnosed cases of classic growth hormone deficiency and were receiving growth hormone therapy for a different period of time in the Department of Paediatrics Military Hospital Rawalpind.Children age less than fourteen years, height less than 0.4 th centile for age on growth charts ${ }^{7}$ and growth hormone deficiency confirmed by at least two provocative tests were included in the study. Children of short stature due to causes other than growth hormone deficiency and age more than 
fourteen years were excluded from the study. Following laboratory tests were carried out before therapy: complete blood count, ESR, urinalysis, serum antitissue transglutaminase (celiac disease), serum urea, electrolytes and creatinin ,karyotype in female patients(turner syndrome), skull X-rays, serum T4, TSH (hypothyroidism, panhypopituitarism) and arterial blood gases.Bone age was determined by radiologists. Following specific tests were carried out to detect classic growth hormone deficiency in short children ;measurement of basal growth hormone level and growth hormone provocative tests (Insulin tolerance test, Levodopa test). A peak GH level of less than $10 \mathrm{ng} / \mathrm{ml}$ in two provocative tests of GH release was considered diagnostic of growth hormone deficiency. Growth hormone replacement therapy with recombinant $\mathrm{GH}$ was given to all children at the dose of $0.14 i u / k g . l t$ was administered subcutaneously in six divided doses. Each patient was assessed and evaluated every three months.

Statistical analysis was performed using SPSS version 10. Student,s t-test was used for comparison. The values of $p<0.05$ were considered to be statistically significant.

\section{RESULTS}

We were following a group of thirty classic short stature children, who were being treated with growth hormone in the Dept of Pediatrics. These children were of different age groups (3-14 years). We assessed / evaluated each patient after a three months interval. Height, weight and height velocity were monitored regularly. Majority $(65 \%)$ of the patients were in age group of 7-10 years. Out of the thirty GH def children $19(63.33 \%)$ were male and 11 (36.66\%) were female patients. Thus male to female ratio was 1.72:1; (Tables-I,II). Growth hormone treatment was administered at the mean chronological age of 8.05 $+/-2.74$ years. Response to $\mathrm{GH}$ was excellent and the mean growth speed had gone up from $2.53+/-0.87$ $\mathrm{cm}$ per year before the treatment to $8.94+/-3.18 \mathrm{~cm}$ / year in the first twelve months of treatment and 6.8
$+/-1.6 \mathrm{~cm} /$ year during the second year of treatment (table-III). An average statural gain of $0.7 \mathrm{SD}$ and a bone maturation gain of one year over one year were achieved.

\begin{tabular}{|l|c|}
\hline Total diagnose cases of isolated GH def & $\mathrm{N}=30$ \\
\hline Age range (years) & $3-14$ \\
\hline Male: Female & $1.72: 1$ \\
\hline Mean chronological age (years) & $8.05+/-2.7$ \\
\hline Mean height- (cm) & $95.27+/-24.43$ \\
\hline Mean bone age (years) & $5.04+/-2.75$ \\
\hline Height SDS score & $-2.16+/-1.01$ \\
\hline Pretreatment height velocity $(\mathrm{cm} / \mathrm{yr})$ & $2.53+/-0.87$ \\
\hline
\end{tabular}

Table-I. Pretreatment Growth Profile of Patients.

\begin{tabular}{|c|c|c|c|}
\hline Age (years) & No(\%) & Male (\%) & Female(\%) \\
\hline $3-4$ & $2(6.66)$ & $2(6.66)$ & Nil (0) \\
\hline $5-6$ & $5(16.63)$ & $3(10)$ & $2(6.66)$ \\
\hline $7-8$ & $8(26.66)$ & $5(16.66)$ & $3(10)$ \\
\hline $9-10$ & $12(40)$ & $7(23.33)$ & $5(16.66)$ \\
\hline $11-12$ & $2(6.66)$ & $1(6.66)$ & $1(6.66)$ \\
\hline $13-14$ & $1(3.33)$ & $1(6.66)$ & $\mathrm{Ni}(0)$ \\
\hline Total & $30(100)$ & $19(63.33)$ & $11(36.66)$ \\
\hline
\end{tabular}

Table-ll. Age and sex wise distribution of children.

During the first twenty four months of treatment, height standard deviation score increased by $1.0+/-$ $0.4 \mathrm{SD}(\mathrm{p}<0.0001)$. None of the children have yet reached final height. Three children ( $1 x$ girl ) have reached pubertal stage 2-3 (Tanner stages of development).

The target height SDS was positively related to the height SDS for chronological age and bone age at start 


\begin{tabular}{|l|c|}
\hline $\begin{array}{l}\text { Time of Evaluation of } \\
\text { Patient }\end{array}$ & Mean Height Velocity $\mathbf{( c m} / \mathbf{~} \mathbf{r})$ \\
\hline Pretreatment & $2.53+/-0.87$ \\
\hline 6 Months & $5.28+/-1.21$ \\
\hline 12 Months & $8.94+/-3.18$ \\
\hline *24 Months & $7.15+/-1.63$ \\
\hline 36 Months & $6.53+/-1.82$ \\
\hline
\end{tabular}

Table-III. Growth profile of children with GH therapy.

of therapy ( $p=0.01, p=0.001$, respectively) and to growth velocity during the first year of therapy $(r=0.29, p=0.001)$. While the SDS of the growth velocity during the first year of therapy was negatively related to chronological age $(p=0.01)$. Their mean bone age was $5.04+/-2.75$ years. We found overall increase in the height velocity, the bone age / chronological age ratio and height SDS for chronological age decreased, while height SDS for bone age increased.

Some children showed very good response, with height velocity of up to twelve $\mathrm{cm}$ per year. Three children have reached a height of $154.54+/-1.45 \mathrm{~cm}$ which was very close to their target height (160.38 $+/-1.39 \mathrm{~cm}$ ). One of our patients, a girl, presented at the age six year. Her height was ninety $\mathrm{cms}$ and weight $10 \mathrm{~kg}$. After one year of treatment with growth hormone an increase in growth velocity $(12 \mathrm{~cm} / \mathrm{yr})$ in the length and in body weight (total body weight $=18$ $\mathrm{kg}$ ) was observed. Patients were assessed thoroughly for complications and untoward effects. Parents and children were cooperative and no compliance with treatment was observed. All these children were doing well. Routine investigations (blood counts, liver function tests, urinalysis and serum electrolytes) were within normal limits during therapy.

\section{DISCUSSION}

Human growth hormone (hGH) has been used for $\mathrm{GH}$ deficiency for more than 40 years $^{11}$. The rhGH has a good safety record and is used worldwide for children with growth hormone deficiency ${ }^{12,13}$. In this study we included 30 classic short children retrospectively and prospectively. We used GH in a dose of $0.14 i \mathrm{iu} / \mathrm{kg} /$ subcutaneously, six days a week at evening, as is used in most of countries ${ }^{14}$. Evening $\mathrm{GH}$ injections have been shown to have greater peak levels than morning administration ${ }^{11}$.

No national data for GH therapy is available to be compared to UK audit for GH prescription ${ }^{15}$. Our patients data are similar to patients in other studies in terms of age and height standard deviation scores at the start of treatment ${ }^{16,17}$. The height velocity observed in them before therapy was less than four $\mathrm{cm}$ per year(mean $=2.53+/-0.87 \mathrm{~cm} /$ year). After $\mathrm{GH}$ replacement therapy response was excellent especially in the first six to twelve months of therapy as is supported by most of studies ${ }^{18,19}$. Subsequently this

\begin{tabular}{|l|c|c|c|c|c|}
\hline Study name & $\begin{array}{c}\text { No of } \\
\text { patients }\end{array}$ & $\begin{array}{c}\text { Mean age at } \\
\text { start (years) }\end{array}$ & Dose GH & $\begin{array}{c}\text { Mean total height } \\
\text { gain in first year }\end{array}$ & $\begin{array}{c}\text { Mean height gain } \\
\text { in second year }\end{array}$ \\
\hline 1. Chen YD, et al ${ }^{8}$ & 23 & 15.5 & $0.27-0.83 \mathrm{in} / \mathrm{kgwk}$ & 10.6 & 08 \\
\hline 2. Holcombe JH, et al & 309 & $8.4+/-3.9$ & 0.48 & $8.9+/-2.2$ & $7.1+/-1.1$ \\
\hline $\begin{array}{l}\text { 3. CMH Rawalpindi } \\
\text { Score }\end{array}$ & 30 & $7.2+/-3.4$ & $0.1 \mathrm{iu} / \mathrm{kg}, 6$ days a week & $15.5+/-4.1$ & $10.4+/-2.8$ \\
\hline Our study & 30 & $8.04+/-2.74$ & $0.14 \mathrm{iu} / \mathrm{kg}, 6$ days a week & $8.94+/-3.18$ & $7.15+/-1.63$ \\
\hline
\end{tabular}

Table-IV. Comparison of height gain in cms over two years with national and international studies. 
growth rate returns slowly to normal values ${ }^{20}$. Some side effects of growth hormone therapy are: peripheral edema, arthralgias, myalgias, back pain, paresthesias, carpel tunnel syndrome, headache, hypertension, rhinitis, flulike symptoms and slipped capital femoral epiphysis ${ }^{21,22,}$. No marked side effect was observed in any patient as in a US study ${ }^{23}$. Auxologic measurement including height velocity ,height deviation score and bone age were recorded on regular basis ${ }^{24}$. We observed positive catch up growth response and proportionate changes in bone age versus height age during treatment. Therapy was well tolerated. There were no significant changes in laboratory safety data or vital signs ${ }^{25}$. After twelve months of GH therapy the growth velocity recorded in sixteen children was7.5+/-2.5 cm $/ \mathrm{yr}^{26}$. In two children GV was $13.5+/-1.3 \mathrm{~cm} / \mathrm{yr}$. In one child GV recorded was $15.4+/-1.2 \mathrm{~cm} / \mathrm{yr}$. This is comparable to a study in India ${ }^{27}$ and a study performed in this centre $^{10}$.

We observed that males outnumbered ie $55 \%$ as compared to $67 \%$ in a USA study ${ }^{29}$.

No bony changes were observed ${ }^{30}$. Clinically no obvious change in fat distribution were observed ${ }^{30}$. There was No fluid retention ${ }^{31}$, psychosocial or observed problem. There result are capable to those of other studies ${ }^{29-33}$.

\section{CONCLUSION}

Short stature with classic growth hormone deficiency though rare but not uncommon. Each child of short stature should be properly evaluated and investigated. Recombinant human growth hormone therapy is quite safe. Early diagnosis and prompt treatment with growth hormone replacement has a very good outcome and the child attains a reasonable height. Copyright@ 18 Jun, 2009.

\section{REFERENCES}

1. H S Randeva and P M G Bouloux. Evaluation of short stature. Student BMJ. May,2000;08:131-174.

2. Jean-Claude Carel, Adult height after long term treatment with recombinant growth hormone for isolated growth hormone deficiency: observational follow up study of the French population based registry. BMJ.July, 2002;325:70.

3. Schwenk WF2nd. Growth hormone therapyestablished uses in short children in USA. Acta Paediatr Suppl.July, 2006;95(452):6-8.

4. Lanes R. Long-term outcome of growth hormone therapy in children and adolescents. Endocrinol,2004;3(1):53-66.

5. De-Zegher-F; Albertesson - Wikland-K; Growth hormone treatment of short children, J-ClinEndocrinol-Metab. 2000 Aug:85(8)2816-21.

6. Denson LA. Growth hormone therapy in children and adolescents: Expert Opin Drug Metab Toxicol. 2008 Dec;4(12):1569-80

7. Growth charts. Uk cross sectional reference data. Child Growth Foundation 1995/l.

8. Chen YD, Shu SG, Chi CS. Growth response and final height in growth hormone deficient children treated with biosynthetic growth hormone. Acts Paediatr Taiwan 2001;42:291-6.

9. Kaplan SL, Underwood LE, August GP, Bell JJ, Blenthen SL, Blizzard RM, et al. Clinical studies with recombinant -DNA-derived methionyl human growth hormone in growth hormone deficient children. Lancet 1986;1:697-700.

10. Aziz S, Ali S, Maqsood U, Sultan M. Badshah S. Response of recombinant human growth hormone in isolated growth. Hormone deficiency. PAFMJ, June, 2007;57(2):129-134.

11. Mehta A, Hindmarsh P. Growth hormone deficiency in children. The Pharmaceutical Journal, June 17, 2000, Vol 264 No 7101 p917-921.

12. Editorial. Growth hormone: uses and abuses. BMJ 17 April 2004;328:907-908.

13. Growth Hormone Deficiency. National Organization for 
Rare Disorders, Inc. 5.4.2008. web site www.rare diseases. Org.

14. Bajpai A. Menon PS. Growth hormone therapy. Department of Pediatrics, All India Institute of Medical Sciences, New Delhi, India.2005. Feb;72(2):139-44.

15. Mehta A and Hindmarch P. Growth hormone deficiency in children. UK Audit of Childhood Growth Homone Prescription,1998. Arch Dis Child 2001;84:387-389.

16. Vance ML and Mauras N. Growth Hormone Therapy in Adults and Children. Act Paedr. October,1999.Vol. 341, 1206-1216.

17. Growth hormone therapy in KIGS. 10 years, experience. Heidelberg. Johann Amrosius 1999;73-80.

18. Lopez-Siguero JP, Garcia E, Carralero I. Adult height in children with short stature treated with growth hormone. J Pediatr Endocrinol Metab. 2000. NovDec;13(9):1595-602.

19. Wasniewska M, ArrigoT, Cisternino M. Long term catch up growth and height prognosis of $\mathrm{GH}$ def children treated on GH. Eur-J-Endocrinol.2000; 142(5)460-5.

20. Hindmarsh PC, Dattani MT. Use of growth hormone in children. NatlinEndocrinol Metabol. 2006 May;2(5):260-8.

21. Darendeler F, Karagiannis G, Wilton. Headache, idiopathic intracranial hypertension and slipped capital femoral epiphysis during growth hormone treatment: a safety update from the KIGS database Horm Res. 2007;68 Suppl 5:41-7.23.

22. Cook, D, Owens, G \& Jacobs, Human Growth Hormone Treatment in Adults: Balancing Economics and Ethics. The American Journal of Managed Care, M. 2004. S417-S419.

23. Steelman J. The GH Monitor SM Registry: an update of the last three years. Vanderbilt Children's Hospital,
USA. Pediatr Endocrinol Rev. 2006 Dec;4 Suppl 1:91-4.

24. Radetti G, Buzi F.A. Four year dose response study of rcomb GH treatment of GH def children. Eur-JEndocrinol.2000;142(1):42-6.

25. Growth response, pubertal growth and final height in Greek children with GH def on long term GH therapy and factors affecting outcome. Journal of Pediatric Endocrinology \& Metabolism. 2001 April. 14(4):397405.

26. Bryant J, Baxter L, Cave CB. Recombinant growth hormone for short stature in children and adolescents. UK, Cochrane Database Syst Rev. 2007 July 18;(3).

27. P.S.N. Menon.GH therapy -Current status. Indian J Paediatr, 1992,58:825-829.

28. Steelman J. The GH monitor SM Registry. Vanderbilt Children's Hospital, USA. Pediatr Endocrinol Rev.2006 Dec;4 Suppl 1:91-4.

29. Conc FN,Kandemir N. Long-term effects of growth hormone (GH) on bone mineral status and bone turnover markers in patients with isolated $\mathrm{GH}$ deficiency. Clin Endocrinol (0xf). 2007 May;66(5): 672-7. Epub 2007 Mar.

30. Roemmich-JN; Sundaresan SM; Rogol-AD. Effects of GH therapy on body fat distribution. Metabolism. 2001. May;50(5):537-47.

31. Wilton-P; Fluid retention in children receiving GH therapy. Horm-Res. 2001.55 Suppl 2:61-4.

32. Keselman-A; Martinez-A; Pantano-L. Psychosocial outcome in GH def children and GH therapy.J-PediatrEndocrinol-Metabol. 2000 Apr;13(4):409-16.

33. Urushihara H, Fukuhara S, TaiS. Quality of life of Japanese hypopituitary children with GH deficiency during GH replacement. Eur J Endocrinol.2007. Jun;156(6):637-45. 


\section{AUTHOR(S):}

1. DR. LT. COL NAYYAR AHMAD, MCPS FCPS

Department of Pediatrics

Military Hospital, Rawalpindi

2. DR. LT. COL. MOHAMMAD TARIQ NADEEM, FCPS

Department of Pediatrics

Military Hospital, Rawalpindi

3. DR. MAJ. ZAMEER AHMAD NAYYAR, FCPS

Department of Pediatrics

Military Hospital, Rawalpindi

\section{Correspondence Address: \\ Dr. LT. Col. Nayyar Ahmad \\ Department of Pediatrics \\ Military Hospital, Rawalpindi \\ drnayyar_68@hotmail.com}

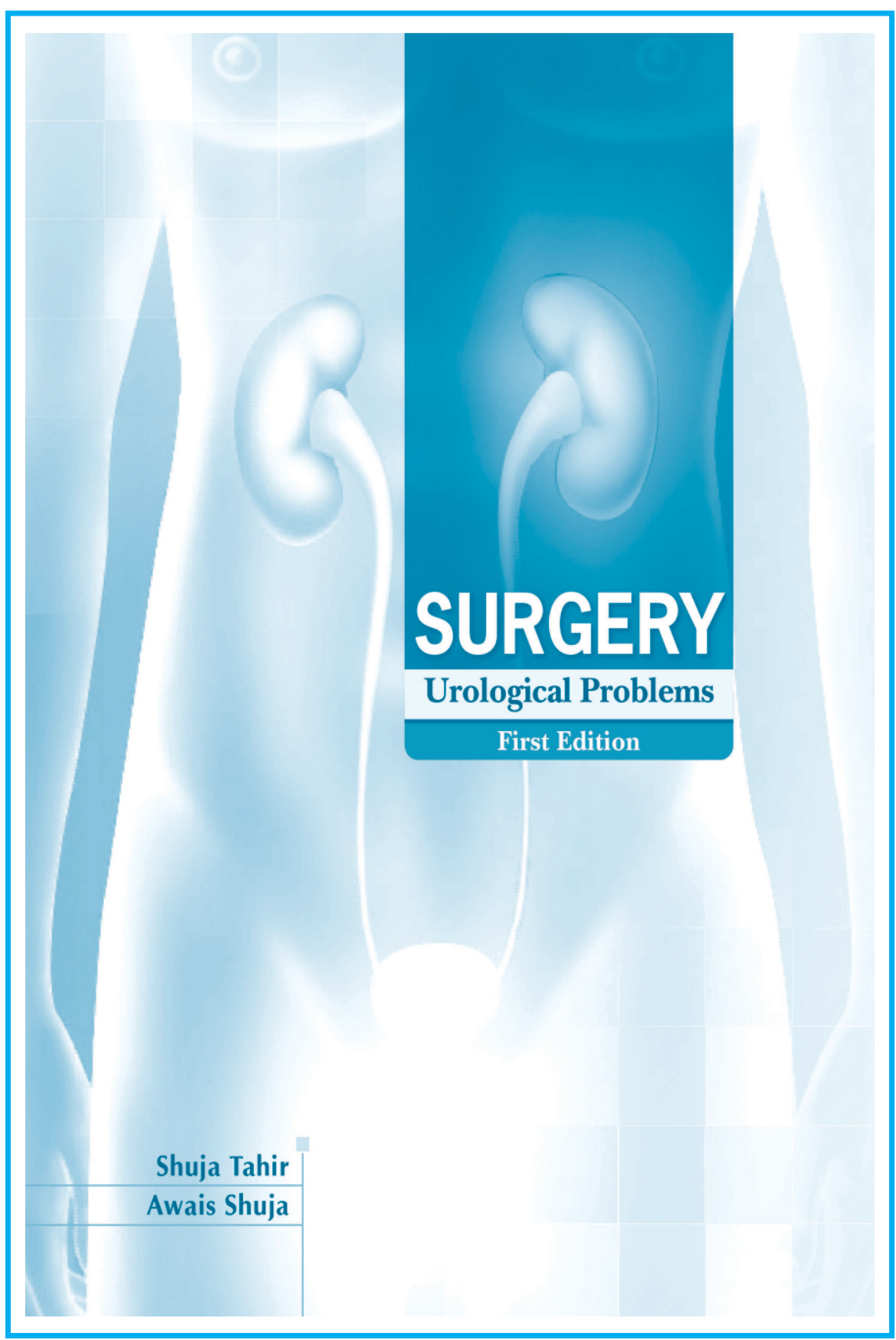

Article received on: 24/03/2009 Accepted for Publication: 18/06/2009 Received after proof reading: 11/02/2013 